\title{
EVALUATION OF EMAS SYSTEM FUNCTIONING IN PRIVATE SECTOR UNITS, DCT GDANSK INCLUDED
}

\author{
Janusz Myszczyszyn ${ }^{1}$, PhD \\ ${ }^{1}$ West Pomeranian University of Technology, Faculty of Economics
}

\begin{abstract}
Despite the growing awareness of societies and the plurality of the ideas of sustainable development, this vision has been still insufficiently introduced into life in many aspects.

The EMAS system, which promotes actions in the sphere of environmental protection to a greater extent than ISO standards, continuous planning of new actions for pro-ecological investments included, can make up an example. Still, the EMAS system is not popular enough, neither in most EU Member States nor in other countries around the world.

Between 2010 and 2016 in Poland, an increased interest in the EMAS system could be noticed but now, a kind of stagnation can be observed. Some entities resign from further taking part in the system, and new ones are far from being numerous. The participation in the system seems not attractive enough from the perspective of private sector entities, which is confirmed by the survey carried out by the author. Despite this, for $93 \%$ of private sector companies surveyed, the EMAS system positively affects the image of the organization rather than the economic effects. This may be signalling some necessary changes in the principles of this system operation.
\end{abstract}

Key words: Eco-Management and Audit Scheme (EMAS), sustainable development, management system, environmental protection, private sector organizations.

JEL code: Q01, Q56

\section{Introduction}

Despite the fact that economic development in the world today is positive in many ways, on the back of this development, in combination with the growing population, is increasing the negative impact on our environment. Further negative effects on the environment must be significantly reduced in order to ensure sustainable development. The use of environmental management systems is an effective tool for the promotion of sustainable development in society.

The role of the private sector in ensuring sustainable development is shown by Development Co-operation Report 2016: the United Nations General Assembly adopted the universal 2030 Agenda for Sustainable Development and its 17 Sustainable Development Goals (SDGs). These goals we need to ensure prosperity and equity for all. To achieve these goals, the participation of the private sector is essential. The private sector can be a powerful actor in promoting sustainable development in ways that go far beyond funding (Development Co- operation Report 2016). Over $70 \%$ of goods in the world are produced by entities referred to as private sector. It is impossible to build a "green economy" without an active one participation of private enterprises (Ostrowiecki, 2015).

Standardised environmental management systems, such as ISO 14001, Eco-Management and Audit Scheme (EMAS), and quality systems such as ISO 9001 are examples of modern management concepts.

EMAS registered organizations play an important role in the future in the propagation of EMAS system in the world and Poland. EMAS system has a chance to exert an important impact on promoting the sustainable development aspects.

The main purpose of the author's own research is to assess the functioning of the EMAS system in Poland on the basis of environmental goals achieved by private sector organizations, including DCT Gdansk, indicated in environmental declarations for the years: 2015, 2016.

While preparing the article, the author assumed the following objectives: 
- to analyse the statistics on the implementation of the EMAS system in Poland and the world;

- to make see that private sector entities can also have a significant influence on the environment and promote sustainable development;

- to indicate the impact of environmental systems on a continuous increase in the awareness of sustainable development in Poland;

- searching for EMAS system barriers and weaknesses for private sector;

- picturing the achieved environmental goals in the case of a selected entity registered in the system for the second year.

To review the research hypothesis posed and research objectives, the author used:

1) Primary materials - results of the author's own research conducted amongst EMAS registered organizations in Poland. The questionnaire survey was conducted between May 2016 and December 2017. 35 organizations, including 15 private sector ones, agreed to participate in the study.

2) Secondary materials, which include: the statistics available under the Community EMAS register, the register kept by the General Directorate for Environmental Protection, Environmental declarations of EMAS registered organizations and sites (especially environmental declarations for 2015 and 2016 for DCT Gdansk), literature on the subject matter.

\section{Research results and discussion}

The European Commission enacted the so-called EC Eco-Audit Regulation in 1993 with focus on the manufacturing industry. The focal point of the revision in 2010 was administrative relief for small and medium-sized enterprises. Furthermore, the revision made it possible for sites outside the EU to participate (Good reasons for EMAS, 2011, Myszczyszyn, 2010, Myszczyszyn, 2017).

Actually, the participation in EMAS scheme is free and open to all kinds of organizations. It is assumed that EMAS shall be made available to all organizations, in and outside the Community, whose activities have an impact on the environment. (Regulation (EC) No 1221/2009).

Organizations, intending to be EMAS registered, among other things, must conduct an environmental review, implement an effective environmental management system, carry out an internal environmental audit, prepare an environmental statement, describing both the environmental management system and the environmental performance results (Act of 15 July 2011, Regulation of the Minister of the Environment of 1 February 2012, Regulation of the Minister of Environment of 23 March 2012).

As of 31th October 2016, the EU EMAS register included 3,943 registered organizations, of which 9,093 sites, and a year later (October 2017) 3,865 organizations and 9,140 sites. The number of organizations decreased by $73(-1.9 \%)$, but the number of sites increased by 43 $(0.5 \%)$. The linear trend for the analysed period (2009-2017), it indicates that on average, the number of entities registered in the EMAS is reduced by 45 every year. These are not optimistic data.

In Poland, the system registered 72 organizations and 358 sites (October 2016), and now 71 organizations and 366 sites. Two new organizations were registered in one year, and three were deleted or suspended (Article 15 Regulation (EC) No 1221/2009 of the European Parliament and of the Council of 25 November 2009) It is only 1.8 organizations per 1 million residents (Sustainable, 2015). But there is an enormous gap between Poland and Germany, Italy, Spain (Myszczyszyn, 2017) (Fig. 1). 
A list of organizations, operating in Poland and tested by the author and those EMAS registered by sections of national economy is shown below (Fig. 2).

The following sections are most strongly represented in EMAS: section E organizations prevail (remediation and other services related to waste management - 23 organizations), together with those of section $O$ (public administration and defence, compulsory social security - 19 organizations) and section $\mathrm{C}$ of industrial manufacturing -15 organizations).

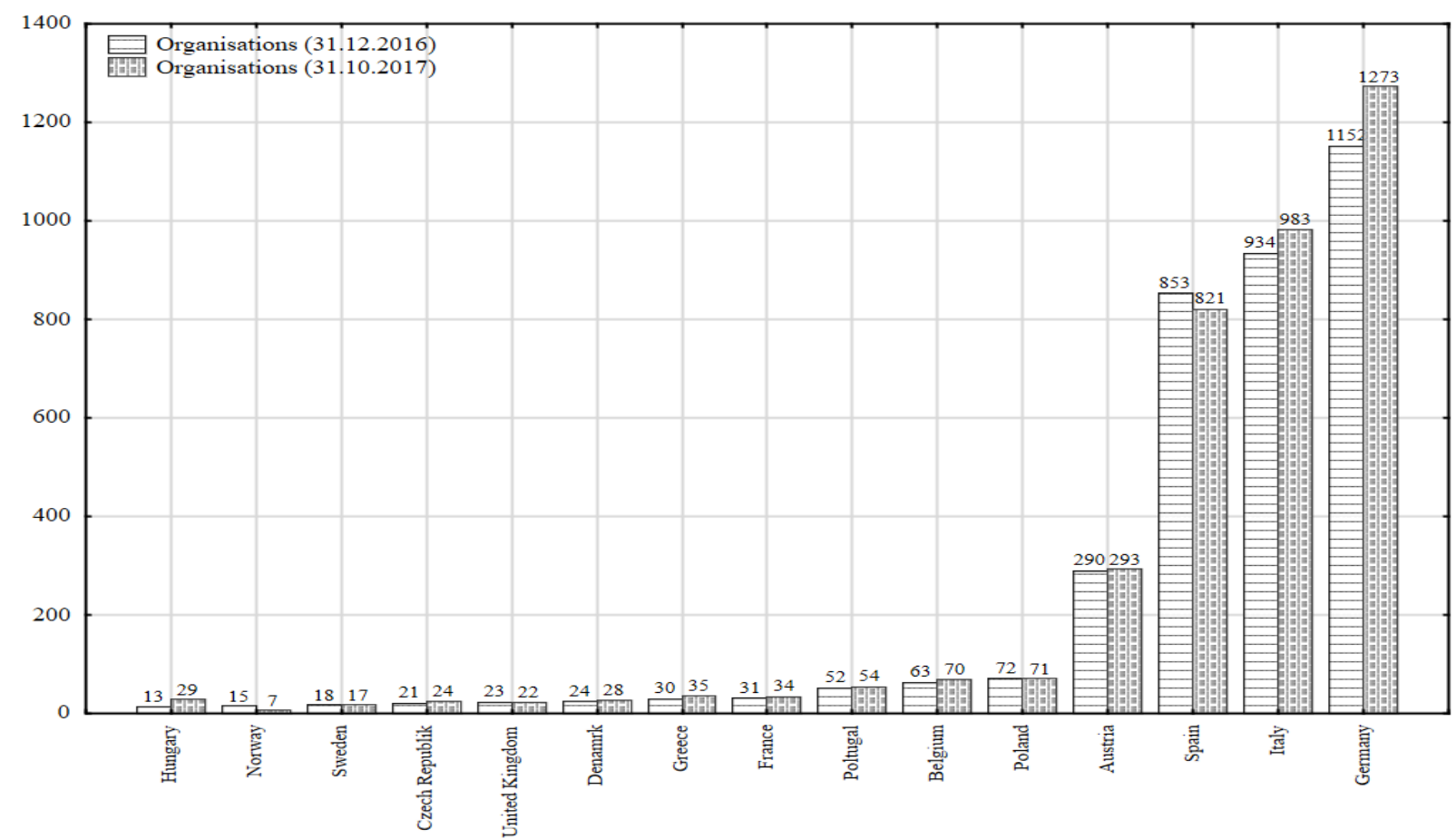

Source: author's calculations based on data: http://ec.europa.eu/environment/emas/register/reports/reports.do (30.12.2016), http://ec.europa.eu/environment/emas/pdf/statistics/PDF_Statistic_November_2017.pdf (28.12.2017)

Fig. 1. The number of registered organizations in the EMAS system in selected countries and Poland (01.12.2016 and October 2017)

No organizations of the following sections have been registered: A - agriculture, shooting and forestry, G- wholesale trade, except for motor vehicles, P - education.

The organizations tested by the author represented sections: O (15 organizations), E (8 organizations), C (6 organizations), D (3 organizations), K (1 organization), H (1 organization), Q (1 organization) (Fig. 2).

The private sector in Poland is represented largely by the company of three sections: C (Manufacturing), E (Water supply; sewerage, waste management and remediation activities), D (Electricity, gas, steam and air conditioning supply), E (water supply; sewerage, waste management and remediation activities) (nearly $90 \%$ of implementations of EMAS). 


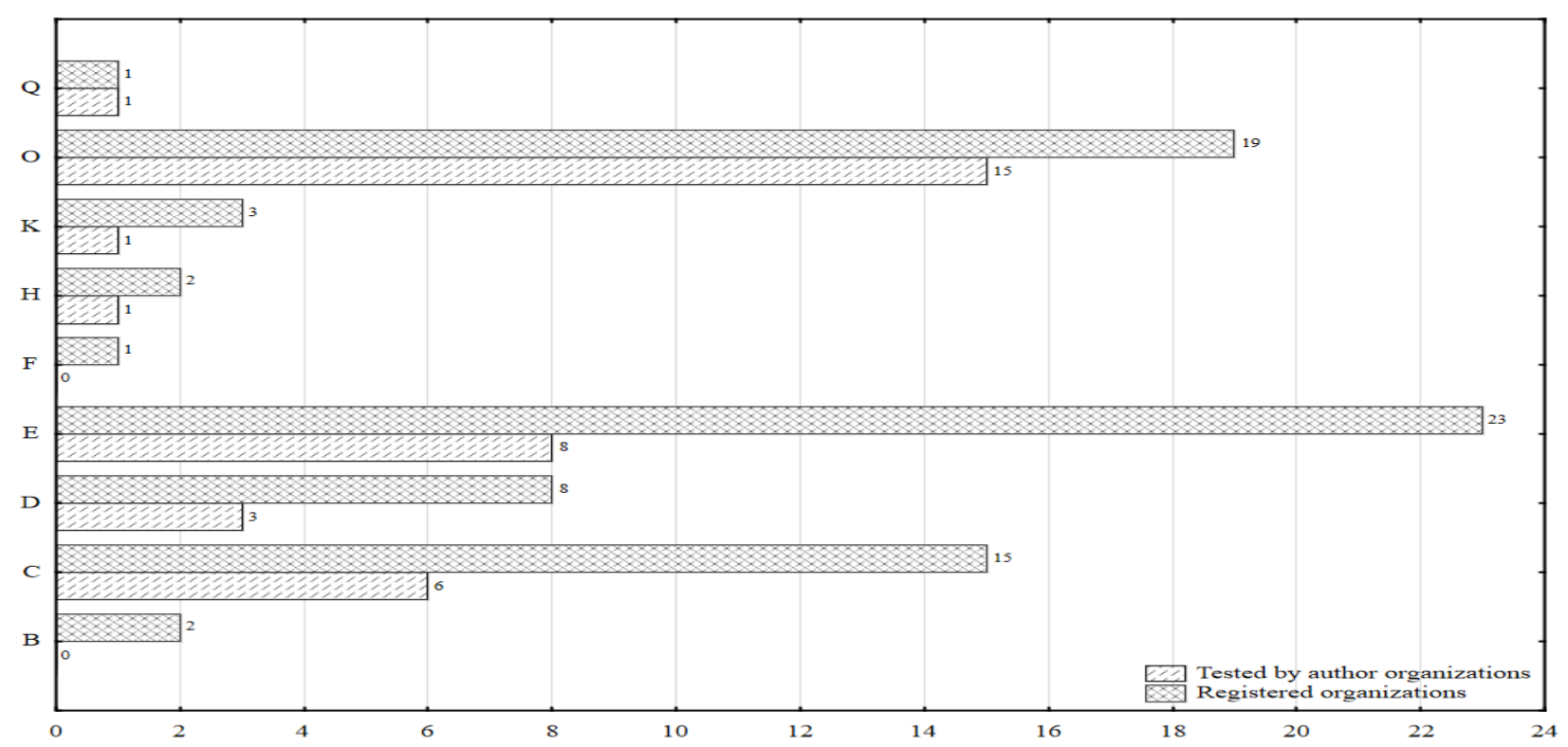

Legend:

$B$ - mining and quarrying, C - manufacturing, D -electricity, gas, steam and air conditioning supply, E - water supply; sewerage, waste management and remediation activities, $\boldsymbol{F}$ - construction, $\boldsymbol{H}$ - transportation and storage, $\boldsymbol{K}-\boldsymbol{f i n a n c i a l}$ and insurance activities, 0 -public administration and defence; compulsory social security, $Q$-human health and social work activities.

Source: author's calculations based on data www.emas.gov.pl (22.12.2017)

Fig. 2. Organizations registered and tested by author in the EMAS in Poland by sections of national economy (14.02.2017)

The respondents of private sector organizations (15 organizations) indicated the following main benefits of the introduction of EMAS:

- improving the image and relations with stakeholders (14 replies);

- increased awareness of the need for action in the field of environmental protection (12 replies);

- continuous improvement, and by the same, an impact on the sustainable development of the country and the world (12 replies);

- more competitive organization (4 replies) impact on the network of suppliers and customers (3 replies), economic and financial benefits (2 replies).

The following financial benefits were underlined, among other things:

- exemption from excise duty (coal);

- reduced waste and costs associated with its management and disposal;

- reduced quantity of raw materials consumed when using new, more efficient and more environment-friendly technologies;

- reduced pollution (greenhouse gas and dust emission along with dirty water discharge), which led to an increase in economic efficiency, but often required capital expenditures being incurred;

- lack or reduced fines paid for environmental pollution; prestige in the external environment, better (ecological) product;

- better living conditions ensured to those around, including the local community in the region. Respondents indicated that despite measurable benefits, EMAS scheme also has weaknesses which include:

- the necessity to set out, document and verify subsequent environmental objectives, means extra costs and, in the case of large environmental goals, it may be difficult to put them into life; 
- the need to develop regular environmental reports, which require the involvement of staff and management, and which may interfere with the on-going activities of the organization;

- no measurable effects in terms, if only, of limiting additional inspections related to environmental protection on behalf of state authorities and public organizations;

- no amenities with respect to grants for direct investments into environmental protection;

- no tax relief nor other benefits, e.g. in tender procedures, applications for EU funds;

- poor promotion of the EMAS logo in Poland, in many cases unknown by other organizations and citizens.

The private sector respondents pointed out that competing companies can easily get access to business information (production process, planned pro-environmental investments etc.), which they claimed to be a threat.

When asked about the main reasons for the implementation of EMAS in their organizations, the respondents indicated:

- needed continuous improvement of their environmental performance, the achievement of the next stage in this sphere included, as they had ISO 14001 system earlier;

- increased prestige of the organization, the promotion of environmental protection in the external environment included;

- increased involvement of employees in achieving environmental objectives;

- promotion of the idea of green management office;

- instruction of the superior authority.

The results of our own research are only a confirmation that the EMAS system is very important for building the company's image, much bigger than the economic effects (over $93 \%$ of the surveyed companies). The author notes that private sector companies would be more likely to implement EMAS if there were more incentives from central and local authorities.

For the purpose of an in-depth analysis (along with the above-mentioned tests), the author also evaluated pro-environmental actions with particular attention focused on the EMAS system in DCT, which joined the EMAS at the end of 2016.

DCT - deep-water container terminal is the only such undertaking on the Baltic Sea, and in addition, this is one of the fastest developing Polish container terminals.

The company has a strictly defined environmental policy, made publicly available in form of Sustainable Development Document, Environmental Declarations.

DCT's sustainable development means: integrated organisation management and achieving business results in a socially responsible manner, reliability and competitiveness in meeting clients' needs and providing them with the highest-quality services, increasing the terminal's capacity and supporting initiatives to expand the supplementary infrastructure in response to cargo volume growth to ensure comprehensive service for customers, innovation in business processes and in purchasing of goods and services, including new technologies and solutions, which ensure accounting for quality, environment, energy and occupational safety factors, execution and optimisation of processes in an energy efficient manner, aimed to provide sustainable energy use reductions, assurance of safe and comfortable working conditions for all employees engaged in all activities on-site, including third parties; adherence to the principle of zero accidents, respect for the environment and the natural world, reducing environmental impacts, execution of investment processes while maintaining bio-diversity, and when necessary, providing compensation measures. 
The Management Board's integrated activities in particular such issues as: quality and client's expectations, in compliance with ISO 9001, energy effectiveness of processes, in compliance with ISO 50001, conditions of safe work, in compliance with OHSAS 18001, environmental protection, in compliance with ISO14001 and EMAS regulation (Declaration of sustainable development of DCT Gdansk SA, 2017).

According to the environmental declarations $(2015,2016)$ the entity, among other things:

- owing to the investments made (purchase of electric cranes, EURO5 class vehicles), reduced fuel consumption, diesel oil included (by approx. $335 \mathrm{~K} \mathrm{I}$ ), reduced the level of exhaust gases emission, extended the dune laboratory (rebuilt and footbridges installed) in order to protect endangered plant species;

- restricted the quantity of waste (re-usable mausers, retreading of tyres) and the area of used oil dumping ground;

- owing to the new T2 terminal being built, it will reduce $\mathrm{CO} 2$ emission by $27 \%$ for road transport and by $40 \%$ in case of maritime transport,

- undertakes numerous compensation actions for the local population (e.g. educational programmes for children and youngsters) (Declaration of sustainable development of DCT Gdansk SA for 2015, 2016).

The entity plans many new environmental targets. It intends to continue the EMAS system.

Its main purpose is not a direct business goal but the requirements of the stakeholders, its better image.

For the purpose of the development of the organisation, the Company's Management Board declare their involvement in these processes, thus taking into account the principles of quality management, ensuring the engagement of competent personnel and resources for the execution of management and technical processes, as well as energy effectiveness and safety processes, their planning, monitoring, review and improvement.

The above analysis taken into account, the author positively concludes that the implementation of environmental management systems, EMAS included, increases the awareness of organizations, institutions, their management and employees, as well as society that the care about environment is needed to contribute to the promotion and implementation of the idea of sustainable development, but the participation in the EMAS system seems not attractive enough from the perspective of private sector organizations (economic goals) (Myszczyszyn, 2009; Myszczyszyn, 2017).

\section{Conclusions, proposals, recommendations}

1) In 2016, expenditures on environmental protection in Poland amounted to $0.35 \%$ of GDP. The share of expenditures on fixed assets for environmental protection in investment expenditure in the national economy was at the level of $2.7 \%$ for environmental protection (5.6 \% in 2015). The main investor in the field of environmental protection in Poland are enterprises (whose share in expenditure in 2016 was about $72 \%$ ), local governments (with a share of about $20 \%$ ), then budgetary units ( $8 \%$ ) (Ochrona Srodowiska, 2017).

Therefore, the importance of the private sector (participation in generating of GDP for Poland over $80 \%$ ) is very important in the promotion of sustainable development.

2) The implementation of the Eco-Management and Audit Scheme is a chance to put into life the sustainable development guidelines. This can also be a chance to the organizations which 
already have ISO 14001 environment management system, to improve their further environmental actions within EMAS. To achieve measurable success in implementing of the EMAS system, the private sector must be involved.

3) The EMAS system is still not popular enough in Poland, and private entities are not eager to extend their earlier environmental policy by the analysed system. The firms of the SMEs sector do not appear to be interested in the system; contrary to ISO Systems, ISO 14001 included. Indeed, there are still many weaknesses of the EMAS system, but it is also a signal for the authorities and the Ministry of Environmental Protection to conduct more effective education, more preferences for environmental companies, more activity in public-private partnership. A lot also depends on the education sector, which should be even more strongly involved in the development of pro-ecological attitudes in the economy.

4) Currently, out of 71 organizations registered in the EMAS system in Poland, only $2 / 3$ belong to the private sector. In accordance with The ISO Survey of Management System Standard Certifications 2016 in the year 2016 (in the world) the system ISO 14001 was implemented in 26,693 organizations (annual growth-8 \%), EMAS - only 15 organizations (annual growth of$0.3 \%$ ) (The ISO Survey of Management System Standard Certifications, 2016). Both Environmental Management Systems (ISO 14001 and EMAS) have the same guarantees, are equally reliable and are very similar, the EMAS regulation being the most restrictive (AlvarezGarcia, Rio Rama, 2016).

5) The author's research (surveys, environmental declarations) is a confirmation that constantly setting new environmental goals (a necessity in the EMAS system) and public reporting of the achieved goals influences the construction of sustainable development. DCT Gdansk has achieved goals like: reduced fuel consumption, diesel oil included (by approx. $335 \mathrm{~K} \mathrm{I}$ ), reduced the level of exhaust gases emission, extended the dune laboratory in order to protect endangered plant species, restricted the quantity of waste and the area of used oil dumping ground, owing to the new $\mathrm{T} 2$ terminal being built, it will reduce $\mathrm{CO}_{2}$ emission by $27 \%$ for road transport and by $40 \%$ in case of maritime transport.

6) Other private sector organizations surveyed also limited consumption of raw materials, gas emissions, noise limitations, implemented modern technologies, more optimal for the environment.

7) Despite their growing awareness of the sustainable development, private sector entities are sceptical of the business effects ( $73 \%$ of the surveyed organizations), arising from the EMAS system being implemented. They make up their mind most frequently so as to improve their image amongst their contractors (93\% of the surveyed organizations) or they imitate the patterns from mother companies, among other things, from Western Europe. The public sector and the state still create too little preference for private companies, but they would expand their pro-ecological activity ( $93 \%$ of the surveyed organizations).

Based on the results of the author (and other authors), it can be concluded that the added value for the private organization through the implementation of EMAS was not significant. As shown by the study, in the opinion of the majority of respondents, the EMAS system rather has not contributed: directly to an increase in the competitiveness of the organization ( $93 \%$ of the surveyed organizations), economic and financial benefits ( $87 \%$ of the surveyed organizations). However, the need to set new environmental objectives and to improve the system, the drawing up further environmental statements had an indirect influence on the increase in innovativeness and 
contributed to confidence in the environs of the organization, to the involvement of employees, the boards included. Private companies seem more interested in economic aspects, such as public funding access and call for tenders (Kivi, Gurvits, 2017; Preziosi, Merli, D'Amico, 2016; Myszczyszyn, 2017).The assumptions of the EMAS scheme of continuous improvement and verification of targets along with laying down new ones make up difficulties to the organizations already registered and a barrier to potentially interested new candidates.

8) As suggested by numerous authors, the implementation of EMAS has an impact on the external and internal benefits gained on suppliers, customers included (Hillary, 2004; White, Lomax, 2010; White, Lomax, Parry, 2010; White, Lomax, Parry, 2014; Myszczyszyn, 2017).

However, the costs of investments in the area of environment may sometimes exceed the shortterm revenues, but the long-term financial benefits and the environmental ones included can be significant.

As shown by the authors, one of the main barriers found in the implementation of EMAS relates to the difficulty of attributing positive outcomes directly to the EMAS (as confirmed by the author's own research).

9) Author believes that more initiatives from the state side and public organizations are strongly required to promote EMAS implementation and to increase the public awareness of the EMAS system, its main benefits and added values (Kivi, Gurvits, 2017).

\section{Bibliography}

1. Alvarez-Garcia J.,del RíoRama M., (2016), Sustainability and EMAS: Impact of Motivations and Barriers on the Perceived Benefits from the Adoption of Standards, J. Sustainability 8 (10), p. 1057.

2. Declaration of Sustainable Development DCT Gdansk SA 30.03.2017 r.: http://dctgdansk.pl/wpcontent/uploads/2014/04/Declaration-of-Sustainable-Dev.-032017.pdf. Access: 22.12.2017.

3. Deklaracja srodowiskowa DCT S.A. za 2016 r. z dnia 17.05.2017 r.: http://dctgdansk.pl/wpcontent/uploads/2014/04/20170614-Deklaracja- \%C5 \%9Brodowiskowa-2016-podpisana.pdf Access: 02.01.2018 (Declaration of sustainable development DCT Gdansk SA for 2016).

4. Deklaracja srodowiskowa DCTA S.A. za 2015 r. z dnia 20.07.2016 r.: https://dctgdansk.pl/wpcontent/uploads/2014/04/DCT_ISO_SC_17.01_Deklaracja- \%C5 \%9Brodowiskowa-zza \%C5 \%82 \%C4 \%85cznikami_20160720_podpisana_zabezpieczona.pdf Access: 02.01.2018 (Declaration of sustainable development DCT Gdansk SA for 2015).

5. Good Reasons for EMAS, 2011 Retrieved: http://www.emas.de/fileadmin/user_upload/06_service/PDFDateien/7-good-reasons-for-EMAS.pdf. Access: 28.12.2016.

6. Hillary R. (2004). Environmental Management Systems and the Smaller Enterprise. Journal of Cleaner Production, 12.

7. Kivi K., Gurvits N. (2017). Eco-Management and Audit Scheme (EMAS) Implementation in the European Union: Survey of Estonian Certified Organisations, European Integration Studies, 2017/11, pp. 211-219.

8. Myszczyszyn J. (2009). Rola wspolnotowego systemu ekozarzadzania i audytu (EMAS) w promowaniu zrownowazonego rozwoju w Polsce (The role of the eco-management and audit scheme (EMAS) in the promotion of sustainable development in Poland), Acta Scientiarum Polonorum (Oeconomia) 8 (4), pp. 127-138.

9. Myszczyszyn J. (2010). Polskie doswiadczenia w implementacji wspolnotowego systemu ekozarzadzania i audytu w swietle najnowszego rozporzadzenia EMAS III (Polish experience with the implementation of community Eco-management and audit scheme in the face of the latest regulation EMAS III), Ochrona Srodowiska i Zasobow Naturalnych nr 44, pp. 44-50.

10. Myszczyszyn J. (2017). Eco-management and Audit Scheme (EMAS) as an Important Element of the Sustainable Development Policy on the Example of Poland, Economic Science For Rural Development, No 45.

11. Ochrona Srodowiska (2017) Glowny Urzad Statystyczny, Warszawa, pp. 43-44.

12. OECD (2016), Development Co-operation Report 2016: The Sustainable Development Goals as Business Opportunities, OECD Publishing, Paris, p. 5.

13. Ostrowiecki D. (2015) Sektor prywatny w swietle wizji zrownowazonego rozwoju dla polskiego biznesu 2050, Bialostockie Studia Prawnicze, Z. 18

14. Preziosi M., Merli R., D'Amico M. (2016). Why Companies Do Not Renew Their EMAS Registration? An Exploratory Research, J. Sustainability 8 (2), p. 191. 
15. Sustainable development in the European Union. (2015) Monitoring Report of the EU Sustainable Development Strategy, Eurostat, Luxembourg: Publications Office of the European Union.

16. The ISO Survey of Management System Standard Certifications 2016, http://isotc.iso.org/livelink/livelink/fetch/8853493/8853511/8853520/18808772/00._Executive_summary_2016_Survey.pdf?nodeid=19208898\&vern um=-2, Access: 28.12.2017.

17. White, G., Lomax, M. (2010). Environmental Management Systems: Costs, Benefits and an Activity Theory Approach to Understanding their Knowledge-generating Capabilities, The Environmentalist, 100.

18. White, G., Lomax, M. Parry, G. (2014). The Implementation of an Environmental Management System in the Not-for-profit Sector, An International Journal, 21 (4).

\section{Legislative acts}

19. Rozporzadzenie Ministra Srodowiska z dnia 1 lutego 2012 r. w sprawie wzoru wniosku o rejestracje organizacji w rejestrze EMAS (Regulation of the Minister of the Environment of 1 February 2012 on the model of the application for registration of organizations in the EMAS register), Dz.U. $2012 \mathrm{nr} 0$ poz. 166.

20. Rozporządzenie Ministra Srodowiska z dnia 23 marca 2012 r. w sprawie wspolczynnikow roznicujacych wysokosc oplaty rejestracyjnej za wpis do rejestru organizacji zarejestrowanych w krajowym systemie ekozarzadzania i audytu (EMAS) (Regulation of the Minister of Environment of 23 March 2012 on the factors differentiating the registration fee for the entry in the register of organizations registered in the national eco-management and audit scheme (EMAS)) (Dz.U. $2012 \mathrm{nr} 0$ poz. 341).

21. Rozporzadzenie Parlamentu Europejskiego i Rady (We) Nr 1221/2009 z dnia 25 listopada 2009 r. w sprawie dobrowolnego udzialu organizacji w systemie ekozarzadzania i audytu we Wspolnocie (EMAS) (Regulation (EC) No 1221/2009 of The European Parliament and of the Council of 25 November 2009 on the voluntary participation by organisations in a Community eco-management and audit scheme (EMAS), repealing Regulation (EC) No 761/2001 and Commission Decisions 2001/681/EC and 2006/193/EC).

22. Ustawa z dnia 15 lipca 2011 r. o krajowym systemie ekozarzadzania i audytu (EMAS), (The Act of July 15 , 2011 on the National Community Eco-Management and Audit Scheme (EMAS)), Dz.U. $2011 \mathrm{nr} 178$ poz. 1060 